\title{
Resistensi Aedes aegypti Terhadap Insektisida: Studi pada Insektisida Rumah Tangga
}

\author{
Suri Dwi Lesmana ${ }^{1 *}$, Esy Maryanti ${ }^{1}$, Lilly Haslinda ${ }^{1}$, Afiata Jazila ${ }^{2}$, Mislindawati ${ }^{1}$
}

\begin{abstract}
Dengue hemorrhagic fever is a public health problem in Pekanbaru. It is transmitted by Aedes aegypti mosquitoes. The use of insecticides to kill vectors is a common practice. It is often used in outbreaks by fogging and daily use of insecticides in households. Household insecticides contain a variety of active ingredients such as organophosphates, carbamates, synthetic pyrethroids, and their combinations. This study aims to determine the sensitivity of Ae. aegypti mosquitoes from various household insecticides. This research was descriptive research by conducting a susceptibility test from World Health Organization. Adult mosquitoes were obtained from the breeding of larvae collected from dengue-endemic areas in Pekanbaru. Three types of insecticides are widely distributed in the market consisting of insecticides X with the active ingredient cypermethrin, transfluthrin, and imiprothrin, insecticide $\mathrm{Y}$ containing transfluthrin, and insecticide $\mathrm{Z}$ containing pralethrin and sifluthrin. Each insecticide was exposed to an adult mosquito by applying insecticides to filter paper and exposed for 1 hour and observed after 24 hours. The death of mosquitoes in the three types of insecticides is less than $80 \%$. Based on the WHO criteria mortality of less than $80 \%$ showed a resistant mosquito. This tendency of resistance is probably caused by long-term continuous use.
\end{abstract}

Keywords: Aedes aegypti, dengue hemorrhagic fever, sensitivity

Demam berdarah dengue (DBD) merupakan salah satu penyakit yang sampai saat ini masih menjadi masalah kesehatan di Indonesia. Penyakit DBD merupakan penyakit infeksi yang dapat mengakibatkan kematian. Hal ini disebabkan karena angka kematian dan morbiditas yang tinggi di dunia dan Indonesia. Aedes aegypti (Ae. aegypti) merupakan vektor utama virus dengue penyakit DBD yang ditularkan melalui gigitan nyamuk. Insidens DBD meningkat di seluruh dunia dalam beberapa dekade terakhir. ${ }^{1}$ World Health Organization (WHO) mencatat jumlah kasus DBD pada tahun 2017 adalah 2,3 juta kasus meningkat dari tahun 2014 yang hanya 1,2 juta kasus. Data dari seluruh dunia menunjukkan Asia menempati urutan pertama dalam jumlah penderita DBD setiap tahunnya dan Indonesia tercatat sebagai negara dengan kasus DBD tertinggi di Asia Tenggara. ${ }^{2}$

\footnotetext{
* Penulis Korespondensi : suri.dwi@lecturer.unri.ac.id

1 KJFD Parasitologi Fakultas Kedokteran Universitas Riau, Pekanbaru, Riau, Indonesia

2 Program Studi Kedokteran Fakultas Kedokteran Universitas Riau, Pekanbaru, Riau, Indonesia
}

Kementerian Kesehatan Republik Indonesia mencatat jumlah penderita DBD di Indonesia pada tahun 2017 sebanyak 59.047 kasus dengan jumlah kematian 444 orang. Incidence rate (IR) mencapai 22,55 per 100.000 penduduk dengan Case Fatality Rate(CFR) mencapai 0,75\%. ${ }^{3}$ Jumlah kasus DBD yang terjadi di Provinsi Riau dilaporkan pada tahun 2017 sebanyak 1.928 orang dengan angka kematian sebanyak 15 orang. ${ }^{4}$

Pada tahun 2017 di Kota Pekanbaru terdapat 598 orang yang menderita DBD yang tersebar di 12 kecamatan. Kecamatan Payung Sekaki merupakan salah satu kecamatan yang memiliki jumlah kasus DBD yang tinggi setiap tahunnya. ${ }^{5}$ Tercatat 145 kasus pada tahun 2016 di Kecamatan Payung Sekaki. ${ }^{5}$ Pada tahun 2018 Kecamatan Payung Sekaki menjadi daerah kedua terbanyak menderita DBD di Pekanbaru. Kecamatan tersebut memiliki empat kelurahan dan Kelurahan Labuh Baru Timur tercatat sebagai kelurahan dengan kasus tertinggi. ${ }^{6}$

Penggunaan insektisida merupakan pilihan utama pengendalian vektor DBD. $^{7}$ Insektisida adalah bahan kimia yang digunakan untuk 
membunuh atau mengendalikan serangga hama. ${ }^{8}$ Insektisida dapat berbentuk padat, larutan atau gas yang bekerja dengan cara mengganggu atau merusak sistem saraf pada serangga. Insektisida yang umum digunakan berasal dari golongan organofosfat, karbamat dan piretroid sintetik atau kombinasinya. Sebagai racun kontak, insektisida yang diaplikasikan langsung menembus integumen serangga (kutikula), trakea atau kelenjar sensorik dan organ lain yang berhubungan dengan kutikula. Bahan aktif insektisida dapat larut pada lapisan lemak kutikula dan masuk ke dalam tubuh serangga. ${ }^{9}$

Penggunaan insektisida digunakan secara luas di masyarakat karena mudah didapat dan relatif murah dan dapat digunakan untuk stadium larva hingga dewasa. Penggunaan insektisida pada stadium dewasa sering dilakukan pada kejadian luar biasa berupa fogging hingga penggunaan insektisida sehari-hari di rumah tangga. Hampir setiap rumah tangga menggunakan insektisida untuk membunuh nyamuk. Penggunaan terus menerus dalam jangka panjang dapat menimbulkan resistensi Ae.aegypti terhadap bahan aktifnya. ${ }^{10}$

Beberapa penelitian sebelumnya mengindikasikan bahwa beberapa daerah di Indonesia, populasi nyamuk Ae. aegypti sudah mulai resisten terhadap berbagai jenis insektisida. ${ }^{11}$ Beberapa penelitian menunjukkan resistensi silang, yaitu timbulnya resistensi terhadap suatu insektisida karena pajanan oleh insektisida lainnya. ${ }^{12}$ Penentuan status kerentanan spesies nyamuk vektor secara berkala diperlukan untuk mendapatkan data dasar deteksi lebih lanjut dan monitoring terjadinya resistensi. Dengan demikian karakteristik potensial terjadinya resistensi dapat diketahui lebih awal untuk pertimbangan strategi pengendalian vektor. ${ }^{13}$ Untuk mengetahui sensitivitas nyamuk terhadap insektisida dapat di lakukan dengan berbagai cara antara lain uji kerentanan bioassay, uji biokimia, WHO susceptibility test, deteksi imunologi, dan uji biomolekular. ${ }^{14,15}$ Penelitian ini dilakukan berdasarkan latar belakang tersebut untuk mengetahui status sensitivitas nyamuk Ae. aegypti di daerah endemis Kelurahan Labuh Baru Timur Kota Pekanbaru terhadap insektisida rumah tangga.

\section{METODE}

Penelitian ini merupakan penelitian deskriptif dan pendekatan cross-sectional. Pada penelitian ini dilakukan uji sensitivitas nyamuk Ae. aegypti terhadap insektisida rumah tangga. Waktu penelitian dilakukan dari bulan November tahun 2018 hingga Juli tahun 2019 dan sudah lulus uji etik oleh Unit Etik Penelitian Kedokteran dan Kesehatan Fakultas Kedokteran Universitas Riau dengan nomor 406/ UN.19.5.1.1.8/UEPKK/2017/rev.

Pengambilan sampel dilakukan di Kelurahan Labuh Baru Timur Kecamatan Payung Sekaki Kota Pekanbaru. Tempat mengembangbiakan dan uji sensitivitas nyamuk Ae. aegypti di Laboratorium Parasitologi Fakultas Kedokteran Universitas Riau. Populasi dari penelitian ini adalah nyamuk Ae. aegypti di Kelurahan Labuh Baru Timur dan dengan jumlah sampel sebanyak 450 ekor nyamuk $A e$ a aegypti yang di kembangbiakan dari larva $A e$. aegypti yang di ambil dari rumah warga di Kelurahan Labuh Baru Timur Kecamatan Payung Sekaki Kota Pekanbaru. Pemilihan tempat dilakukan dengan metode purposive sampling karena Kelurahan Labuh Baru Timur memiliki banyak jumlah kasus DBD. Pemilihan Rukun Tetangga dan rumah menggunakan metode consecutive sampling.

Variabel penelitian adalah sensitivitas nyamuk Ae. aegypti terhadap insektisida rumah tangga. Alat dan bahan yang digunakan adalah Tabung WHO yang terdiri dari dua tabung kontrol dan empat tabung uji untuk 60 menit dan tabung holding (penyimpanan) untuk 24 jam, mikropipet volume $1 \mathrm{cc}$, aspirator, paper cup, pengukur waktu, spidol, sarung tangan sekali pakai, pelet ikan, kapas, air. Insektisida rumah tangga yang dilakukan pengujian terdiri dari tiga bahan yaitu insektisida $\mathrm{X}$ dengan bahan aktif sipermetrin, transflutrin dan imiprotrin; insektisida $Y$ dengan bahan aktif transflutrin dan insektisida $\mathrm{Z}$ dengan bahan aktif praletrin dan siflutrin. Kemudian ketiga insektisida tersebut diteteskan masing-masing sebanyak 1 cc pada kertas saring. Nyamuk yang digunakan pada uji ini adalah nyamuk Ae.aegypti dewasa yang dipelihara di Laboratorium Parasitologi FK UNRI.

Uji sensitivitas dilakukan berdasarkan metode uji suseptibilitas WHO. Masing-masing insektisida membutuhkan 150 ekor nyamuk uji. Masingmasing tabung uji dipaparkan 25 ekor nyamuk. 
Suri Dwi Lesmana, dkk, Resistensi Aedes aegypti Terhadap Insektisida: Studi pada Insektisida Rumah Tangga

Interpretasi hasil uji sensitivitas dilihat dari proporsi kematian nyamuk 24 jam. Pengamatan knock down time dilakukan pada kurun waktu 5, 10, 15, 20, 30, dan 60 menit dan selanjutnya dihitung kematian nyamuk setelah 24 jam. Pada interpretasi 24 jam kategori rentan jika kematian lebih besar atau sama dengan 99-100\%, toleran jika kematian nyamuk $80-98 \%$ dan resisten jika kematian nyamuk kurang dari $80 \%$. Jika kematian pada tabung kontrol antara
5-20\%, hasil yang didapatkah harus dikoreksi dengan rumus Abbot. Jika kematian pada kelompok kontrol lebih dari $20 \%$ penelitian harus diulang.

\section{HASIL}

Pada periode paparan selama satu jam diamati proses knock down nyamuk tiap lima menit. Knock down nyamuk selama satu jam pertama dapat dilihat pada tabel 1 .

Tabel 1. Persentase Knock Down Nyamuk Uji Terhadap Insektisida Rumah Tangga X, Y, dan Z Pada Satu Jam Paparan

\begin{tabular}{|c|c|c|c|c|c|c|}
\hline \multirow{2}{*}{ Kelompok } & \multicolumn{6}{|c|}{ Knockdown pada paparan menit ke- } \\
\hline & 5 & 10 & 15 & 20 & 30 & 60 \\
\hline Kontrol X1 & 0 & 0 & 0 & 0 & 0 & 0 \\
\hline Kontrol X2 & 0 & 0 & 0 & 0 & 0 & 0 \\
\hline $\mathrm{X} 1$ & 3 & 7 & 13 & 15 & 17 & 17 \\
\hline $\mathrm{X} 2$ & 3 & 5 & 10 & 12 & 14 & 14 \\
\hline $\mathrm{X} 3$ & 3 & 7 & 14 & 16 & 18 & 18 \\
\hline $\mathrm{X} 4$ & 2 & 5 & 10 & 11 & 13 & 13 \\
\hline Kontrol Y1 & 0 & 0 & 0 & 0 & 0 & 0 \\
\hline Kontrol Y2 & 0 & 0 & 0 & 0 & 0 & 0 \\
\hline Y1 & 11 & 12 & 18 & 20 & 23 & 25 \\
\hline Y2 & 10 & 10 & 17 & 20 & 22 & 25 \\
\hline Y3 & 11 & 12 & 18 & 19 & 21 & 25 \\
\hline Y4 & 9 & 12 & 18 & 20 & 22 & 25 \\
\hline Kontrol Z1 & 0 & 0 & 0 & 0 & 0 & 0 \\
\hline Kontrol Z2 & 0 & 0 & 0 & 0 & 0 & 0 \\
\hline $\mathrm{Z1}$ & 20 & 24 & 24 & 24 & 24 & 24 \\
\hline $\mathrm{Z} 2$ & 19 & 25 & 25 & 25 & 25 & 25 \\
\hline $\mathrm{Z} 3$ & 21 & 24 & 24 & 24 & 24 & 24 \\
\hline Z4 & 20 & 24 & 24 & 24 & 24 & 24 \\
\hline
\end{tabular}

Setelah paparan selama satu jam, nyamuk uji selanjutnya dipindahkan ke tabung pengamatan dan diamati hingga 24 jam. Pengamatan kematian nyamuk setelah 24 jam dapat dilihat pada tabel 2.

Tabel 2. Persentase Kematian Nyamuk Aedes aedgypti Terhadap Insektisida Rumah Tangga X, Y, dan Z Pada Pengamatan 24 Jam

\begin{tabular}{lcc}
\hline Kelompok & Kematian 24 Jam & Rerata Kematian 24 Jam (\%) \\
\hline Kontrol X1 & 0 & 0 \\
Kontrol X2 & 0 & 47 \\
X1 & 12 & \\
X2 & 11 & 0 \\
X3 & 12 & 0 \\
X4 & 12 & \\
\hline Kontrol Y1 & 0 & 78 \\
Kontrol Y2 & 0 & \\
Y1 & 20 & 0 \\
Y2 & 19 & \\
Y3 & 19 & \\
Y4 & 20 & 77 \\
Kontrol Z1 & 0 & \\
Kontrol Z2 & 0 & \\
Z1 & 20 & \\
Z2 & 20 & \\
Z3 & 18 & \\
Z4 & 19 & \\
\hline
\end{tabular}


Dari hasil penelitian terlihat bahwa pada kelompok kontrol kematian nyamuk dalam 24 jam pengamatan adalah $0 \%$ sehingga persentase kematian pada kelompok uji tidak perlu diuji menggunakan rumus Abbott. Kematian terendah adalah pada insektisida $X$ yaitu $47 \%$. Insektisida $X$ meerupakan insektisida paling banyak digunakan masyarakat yang mengandung bahan aktif sipermetrin, transflutrin and imiprotrin. Ketiga bahan aktif tersebut merupakan golongan piretroid sintetik. Dari tabel 2 dapat dilihat rerata kematian nyamuk dari ketiga jenis insektisida kurang dari $80 \%$. Berdasarkan kriteria WHO kematian nyamuk kurang dari $80 \%$ mengindikasikan resisten.

\section{PEMBAHASAN}

Resistensi nyamuk Ae.aegypti terhadap insektisida dapat dilakukan dengan berbagai cara salah satunya melalui uji suseptibilitas dari WHO. Berdasarkan uji tersebut didapatkan Ae. Aegypti terindikasi resisten terhadap insektisida rumah tangga di Kecamatan Payung Sekaki Pekanbaru. Pada pengamatan satu jam pertama untuk melihat fase knockdown terlihat bahwa sebagian besar nyamuk mengalami knockdown pada satu jam paparan namun nyamuk-nyamuk tersebut tidak mati setelah pengamatan 24 jam. Knockdown dan kematian terendah terlihat pada insektisida $\mathrm{X}$. Fenomena ini mengindikasikan kemampuan nyamuk untuk menetralisir insektisida dengan berbagai adaptasi pada tubuhnya. Uji sensitivitas lain yang dapat digunakan adalah uji biokimia yang bertujuan untuk mendeteksi peningkatan enzimatik serta uji serologi dan terakhir uji biomolekular. Untuk mengetahui pasti jenis insektisida dan mekanisme penyebab terjadinya resistensi pada daerah dengan latar belakang pemakaian insektisida yang bermacam-macam sebaiknya dilakukan uji suseptibiltas, uji biokimia serta uji biomolekular. ${ }^{17}$

Ditemukannya indikasi resistensi Ae.aegypti terhadap insektisida rumah tangga di daerah endemis DBD di Pekanbaru ini dapat disebabkan penggunaan insektisida jangka panjang dengan dosis subletal. Nyamuk yang terpapar dosis subletal dapat menjadi resisten dan sifat resisten tersebut akan diturunkan ke generasi berikutnya sehingga seluruh populasi dapat menjadi resisten. Insektisida rumah tangga yang beredar di pasaran pada umumnya mengandung bahan aktif piretroid sintetik dan karbamat. ${ }^{17}$

Resistensi adalah kemampuan suatu populasi serangga untuk bertahan terhadap dosis insektisida letal terhadap spesies serangga tersebut. Resistensi serangga dapat dibagi menjadi resistensi bawaan dan didapat. Selain itu dikenal istilah resistensi kelakuan yaitu kemampuan suatu strain serangga untuk menghindarkan kontak dengan insektisida (insecticides avoidance).

Secara garis besar ada dua hal yang mendasari terjadinya resistensi yaitu dasar fisiologik dan dasar genetika. ${ }^{1718}$ Pada dasar fisiologik segala proses terjadi karena adaptasi fisiologis serangga yang disebabkan oleh daya absorbsi insektisida yang sangat lambat, daya penyimpanan insektisida dalam jaringan non-vital seperti jaringan lemak, daya ekskresi insektisida yang cepat, dan detoksikasi insektisida oleh enzim. Mekanisme genetika juga memainkan peranan terjadinya resistensi seperti pada proses metabolik dan perubahan sisi target. Resistensi terhadap insektisida merupakan proses evolusi sebagai upaya adaptasi terhadap perubahan lingkungan..$^{19,20}$

Secara umum mekanisme terjadinya
resistensi serangga terhadap insektisida diklasifikasikan menjadi tiga kelompok yaitu resistensi kutikuler (penurunan penetrasi), resistensi metabolik dan perubahan sisi target. Pada resistensi metabolik terjadi perubahan enzim secara kualitatif dan kuantitatif yang berfungsi memetabolisme insektisida sebelum mencapai sisi target dan mendetoksikasi xenobiotik.

Kelurahan Labuh Baru Timur merupakan salah satu Kelurahan dengan kejadian DBD yang tinggi dan kepadatan larva yang tinggi. ${ }^{21}$ Faktor resistensi vektor dapat berkontribusi akan kondisi tersebut. Insektisida rumah tangga bermerk X, Y, dan $Z$, yang digunakan pada pengujian mengandung bahan aktif berbagai piretroid sintetik. Insektisida $\mathrm{X}$ merupakan jenis yang paling dikenal dan paling laris di pasaran. Piretroid merupakan racun axononi, yang memiliki efek terhadap serabut saraf. Zat aktif terikat pada protein dalam saraf yang dikenal sebagai voltage-gated sodium channel. Pada keadaan normal, protein ini membuka untuk memberikan rangsangan pada saraf dan menutup untuk menghentikan sinyal. Piretroid terikat pada 
Suri Dwi Lesmana, dkk, Resistensi Aedes aegypti Terhadap Insektisida: Studi pada Insektisida Rumah Tangga

gerbang ini dan mencegah penutupan secara normal sehingga menghasilkan rangsangan saraf terus menerus mengakibatkan tremor dan gerakan inkoordinasi pada serangga. ${ }^{16,18}$

Cara penggunaan dan prosedur yang sesuai dengan petunjuk serta frekuensi penggunaan insektisida yang terkontrol merupakan faktor penting pencegahan resistensi. Di samping itu penggunaan insektisida dengan bahan aktif yang berbeda secara bergantian dirumah tangga seperti insektisida dari golongan organofosfat, golongan karbamat dan insektisida golongan lain selain piretroid sintetik dapat dipertimbangkan untuk mencegah resistensi.

Penelitian ini sejalan dengan penelitian di Kelurahan Cibabat, Cimahi, yang menggunakan satu jenis bahan aktif piretroid sintetik yang melaporkan penurunan status resistensi nyamuk uji yang berasal dari terhadap cypermethrin $0,05 \%$ setelah satu tahun sebelumnya di lokasi yang sama dilakukan penelitian uji resistensi, dan dinyatakan bahwa penggunaan cypemethrin masih toleran. ${ }^{19}$ Hasil yang berbeda didapatkan pada peneltian yang dilakukan di wilayah Pasar Tua Bitung menggunakan insektisida cypermethrin 0,5\% didapatkan status kerentanan nyamuk Ae. aegypti masih toleran. ${ }^{22}$ Di Indonesia sendiri cypermethrin digunakan mulai untuk pengendalian rayap, nyamuk, lalat, lipas dan bahkan juga semut. ${ }^{23}$

\section{SIMPULAN}

Nyamuk Aedes aegypti di daerah endemis demam berdarah dengue Pekanbaru terindikasi resisten terhadap tiga jenis insektisida rumah tangga Perlu dilakukan uji lanjutan untuk mengetahui proses resistensi metabolik hingga genetik.

\section{DAFTAR PUSTAKA}

1. Kementrian Kesehatan RI. Demam berdarah dengue Tahun 1968-2019. Jakarta: Buletin Jendela Epidemiologi; 2010(2).p1-14.

2. World Health Organization. Dengue and severe dengue. April 2017 [dikutip: 31 oktober 2017]. Available from: http://www.who.int/mediacentre/ factsheets/fs117/en/.
3. Departemen Kesehatan (Depkes) Republik Indonesia. Profil kesehatan Indonesia tahun 2017 di Jakarta;2017

4. Dinas Kesehatan Provinsi Riau. Profil Kesehatan Provinsi Riau 2016. Pekanbaru.2017:36-7.

5. Dinas Kesehatan Kota Pekanbaru. Laporan kasus angka kejadian demam berdarah dengue tahun 2017 di Pekanbaru:2017

6. Dinas Kesehatan Kota Pekanbaru. Laporan kasus angka kejadian demam berdarah dengue tahun 2016 di Pekanbaru:2016

7. Sigit SH, Hadi UK. Hama pemukiman Indonesia (pengenalan, biologi dan pengendalian). Bogor: Unit Kajian Pengendalian Hama Pemukiman Fakultas Kedokteran Hewan Istitut Pertanian Bogor; 2006.

8. Wahyudi D. Uji kerentanan nyamuk vektor Aedes aegypti terhadap insektisida yang digunakan dalam program pengendalian demam berdarah dengue (DBD) di Kota Cimahi Provinsi Jawa Barat. 2009

9. Rahardjo G. Resistance status and mechanism of Aedes aegypti (Diptera: Culiccidae) from several cities in Indonesia to pyrethroid insecticides. Bandung: School of Life Science and Technology ITB; 2008.

10. WHO dan Departemen Kesehatan RI. pencegahan dan penanggulangan penyakit demam dengue dan demam berdarah dengue. Jakarta: Depkes RI; 2003.

11. Johnson PW. Chemical resistance in livestock. Elizabeth McArthur Agricultural Institute: Camden NSW; 1998.

12.WHO. Expert comittee on vector biology and control. Vector Resistance to Pesticide. WHO Technical Report Series, No. 818. WHO. Geneva. 62p. 1992.

13.Harris AF, Rajatileka S, Ranson H. Pyrethroid resistance in Aedes aegypti from Grand Cayman. Am. J. Trop. Med. Hyg. 2010; 83(2): 277-84.

14. Yanola J, Somboon P, Walton C, Nachaiwieng W, Prapanthadara L. A novel F1552/C1552 point mutation in the Aedes aegypti voltage-gated sodium channel gene associated with permethrin 
resistance. Pestic Biochem Phys. 2010; 96:12731.

15. Soedarto. Penyakit menular di Indonesia. Jakarata: Sagung Seto;2009.

16.Djojosumarto P. Pestisida dan aplikasknya. Jakarta: PT Agromedia Pustaka; 2008.

17. Macoris Mde L, Andrighetti MT, Otrera VC, Carvalho LR, Junior AL, Brogdon WG. Association of insecticide use and alteration on Aedes aegypti susceptibility status. Mem Inst Oswaldo Cruz, Rio de Janeiro 2007;102(8):895900

18. Andiarsa D, Sembiring WRSG. Behavior of insecticide use in household on three districts / cities of South Sulawesi. J Health Epidemiol Commun Dis. 2015;5(3):149-54

19. Wahyudi D. Uji kerentanan nyamuk vektor Aedes aegypti terhadap insektisida yang digunakan dalam program pengendalian demam berdarah dengue (DBD) di Kota Cimahi Provinsi Jawa Barat. 2009
20.Lesmana SD. Resistensi Aedes aegypti terhadap insektisida golongan organofosfat. J Ilmu Kedokt. 2017;4(1):10.

21.Maryanti M, Lesmana SD, Triguna D, Plymoth M, Harmas W, Delly D, et al. Maya Index dan kepadatan larva Aedes aegypti di daerah endemis demam berdarah dengue Kelurahan Labuh Baru Timur Kecamatan Payung Sekaki Kota Pekanbaru. J Ilmu Kedokt. 2019;12(1):19-24.

22.Karauwan IG, Bernadus JBB, Wahongan GP. Uji resistensi nyamuk Aedes Aegypty dewasa terhadap cypermethrin di daerah Pasar Tua Bitung. Jurnal Penelitian. Fakultas Kedokteran Universitas Sam Ratulangi. Manado. 2017

23.Sunaryo, Ikawati B, Rahmawati, Widiastuti D. Status resistensi vektor demam berdarah dengue (Aedes aegypti) terhadap malathion $0,8 \%$ dan permethrin $0,25 \%$ di Provinsi Jawa Tengah. J Ekol Kesehat. 2014;12(2):146-52. 